\section{Per capita versus adult-equivalent estimates of calorie availability in household budget surveys}

\author{
Estimativa domiciliar da disponibilidade calórica \\ per capita versus adulto-equivalente em pesquisa \\ de orçamento familiar
}

\footnotetext{
1 Núcleo de Pesquisas Epidemiológicas em Nutrição e Saúde, Universidade de São Paulo, São Paulo, Brasil 2 Faculdade de Medicina, Universidade de São Paulo, São Paulo, Brasil.

3 Faculdade de Saúde Pública, Universidade de São Paulo, São Paulo, Brasil. 4 Instituto de Economia Agrícola, Secretaria da Agricultura e Abastecimento do Estado de São Paulo, São Paulo, Brasil.

Correspondence R. M. Claro Núcleo de Pesquisas Epidemiológicas em Nutrição e Saúde, Universidade de São Paulo.

Av. Dr. Arnaldo 715, São Paulo, SP 01246-904, Brasil. rclaro@usp.br
}

\section{Abstract}

This study aims to estimate an adult-equivalent scale for calorie requirements and to determine the differences between adult-equivalent and per capita measurements of calorie availability in the Brazilian population. The study used data from the 2002-2003 Brazilian Household Budget Survey. The calorie requirement for a reference adult individual was based on the mean requirements for adult males and females $(2,550 \mathrm{kcal} / \mathrm{day})$. The conversion factors were defined as the ratios between the calorie requirements for each age group and gender and that of the reference adult. The adult-equivalent calorie availability levels were higher than the per capita levels, with the largest differences in rural and low-income households. Differences in household calorie availability varied from 22kcal/day (households with adults and an adolescent) to 428kcallday (households with elderly individuals), thus showing that per capital measurements can underestimate the real calorie availability, since they overlook differences in household composition.

Food Consumption; Nutrition Surveys; Energy Requirement
Rafael Moreira Claro 1 Renata Bertazzi Levy 1,2 Daniel Henrique Bandoni 3 Lenise Mondini 4

\section{Introduction}

Household budget surveys have been used to measure household food availability based on food expenditures ${ }^{1}$. Although they do not provide a direct measurement of individual food consumption, unlike dietary surveys, they do allow capturing wide variability in food consumption for a significant portion of the population, and at a relatively low cost, besides allowing the disaggregation of information according to socioeconomic strata and geographic regions 2 . In addition, the periodic implementation of household budget surveys allows identifying trends in the population's eating patterns over time 3 .

Studies that assess food consumption based on household food availability generally overlook the impact of family composition on this information, basing their analyses on per capita estimates. Such a strategy leads to a gap between these estimates and real family food consumption, since they fail to consider the presence of family members with distinct energy needs, like children ${ }^{4}$. Thus, adult-equivalent scales are useful tools for narrowing the difference between such estimates and real food consumption and allowing the comparison of data for families with different compositions. This tool allows identifying the contribution of various family members to the overall household food consumption pattern, unlike per capita measurements 5 . 
Adult-equivalent scales are generally used in economic studies to allow comparison of expenses and purchases by households with different family compositions 6,7 . However, few studies have focused on the use of adult-equivalent scales to assess dietary patterns 8,9,10. The current study aims to estimate an adult-equivalent scale for calorie requirements and identify the magnitude of the resulting differences as compared to per capita measurements of calorie availability in the Brazilian population, according to different economic strata and geographic regions, using data from the Brazilian Household Budget Survey (HBS) 2002-2003 conducted by the Brazilian Institute of Geography and Statistics (IBGE).

\section{Methodology}

\section{Sample}

The current study used data from the HBS 11 conducted by the IBGE from July 2002 to June 2003 in a probabilistic sample of 48,470 Brazilian households. The 2002-2003 survey used a cluster sampling plan, probabilistically selecting census tracts in the first stage and randomly selecting households in the second. For the selection process, the tracts of the 2000 Demographic Census (IBGE. http://www.ibge.gov.br) were stratified into groups highly homogeneous with respect to geographic and socioeconomic characteristics. Variables considered in stratification were the location of the tract (Region, State, state capital/metropolitan area/non-capital, urban/rural) and the socioeconomic status of the tract's households (represented by the mean years of schooling of heads of household, according to the 1996 population count) of each one of the geographic sites. This process led to 443 strata of geographically and socioeconomically homogeneous households. Households within each tract were selected by simple random sampling without reposition. Household visits were carried out uniformly throughout the study's four trimesters, so as to reproduce the seasonal variation in income and food purchases.

The principal information from the 2002-2003 HBS analyzed in this study included the food and beverage purchases for household consumption recorded in a household expense booklet kept by the residents themselves (or by the interviewer when necessary) for seven consecutive days.

\section{Analytical procedures}

\section{- Adult-equivalent conversion factors}

To determine the adult-equivalent reference scale, we estimated the mean calorie requirements for men and women from 19 to 50 years of age, resulting in a reference value of $2,550 \mathrm{kcal}$, in accordance with the Food and Nutrition Board guidelines 12 .

The adult-equivalent fraction assigned to each individual was determined by the ratio between the calorie requirements (according to age, gender, and pregnant or breastfeeding status) and the estimated adult reference value $(2,550 \mathrm{kcal})$. The fractions varied from 0.29 for newborns to 1.18 for males from 15 to 18 years of age (Table 1).

\section{- Estimated calorie availability}

Initially, the records on purchases of a given food by the same household were added (a total of some 1,300 foods were mentioned). When applicable, the non-edible fraction of the food was excluded according to the corresponding correction factors 13 . Subsequently, the total amount of each food purchased was converted into calories (kcal), using the AQUINUT software, version 1.0 (NUPENS - Núcleo de Pesquisas Epidemiológicas em Nutrição e Saúde, http://www.fsp.usp.br/nu pens), constructed mainly with the database from the Brazilian Food Composition Table (TACO, version 2. Núcleo de Estudos e Pesquisas em Alimentação, Universidade Estadual de Campinas, Campinas, Brazil), and for foods not included in the above table, with the database from the United States official food composition table, version 15 (Department of Agriculture; http://www.nal.usda.gov/fnic/foodcomp). The food purchase records from the household belonging to the same strata were then added to provide the total strata calorie availability. The amount of energy acquired (kcal/day) was expressed both in adult-equivalent and per capita units, dividing the total calories acquired by the number of food consumption recording days (seven) and then by the total number of adultequivalent units or household members.

\section{- Socio-demographic variables}

The mean household income in Brazilian Reais/ person/month was calculated by dividing the total monthly incomes of the strata members by the total number of residents in the strata, subsequently expressed as income tertiles. Characterization of the study units was completed with 
Table 1

Adult-equivalent conversion factors for estimated calorie requirements according to age and gender.

\begin{tabular}{|c|c|c|}
\hline Age (years) & Calories * (kcal) & $\begin{array}{l}\text { Adult-equivalent } \\
\text { conversion factor }\end{array}$ \\
\hline \multicolumn{3}{|l|}{ Newborns } \\
\hline $0-1$ & 750 & 0.29 \\
\hline \multicolumn{3}{|l|}{ Children } \\
\hline $1-3$ & 1,300 & 0.51 \\
\hline $4-6$ & 1,800 & 0.71 \\
\hline $7-10$ & 2,000 & 0.78 \\
\hline \multicolumn{3}{|l|}{ Men } \\
\hline $11-14$ & 2,500 & 0.98 \\
\hline $15-18$ & 3,000 & 1.18 \\
\hline $19-24$ ** & 2,900 & 1.14 \\
\hline $25-50 * \star$ & 2,900 & 1.14 \\
\hline $51+$ & 2,300 & 0.90 \\
\hline \multicolumn{3}{|l|}{ Women } \\
\hline $11-14$ & 2,200 & 0.86 \\
\hline $15-18$ & 2,200 & 0.86 \\
\hline $19-24$ ** & 2,200 & 0.86 \\
\hline $25-50$ ** & 2,200 & 0.86 \\
\hline $51+$ & 1,900 & 0.75 \\
\hline \multicolumn{3}{|c|}{ Breastfeeding women $(+500 \mathrm{kcal}) * \star \star$} \\
\hline $11-14$ & 2,700 & 1.06 \\
\hline $15-18$ & 2,700 & 1.06 \\
\hline $19-24$ & 2,700 & 1.06 \\
\hline $25-50$ & 2,700 & 1.06 \\
\hline $51+$ & 2,400 & 0.94 \\
\hline \multicolumn{3}{|c|}{ Pregnant women $(+300 \mathrm{kcal})$ \# } \\
\hline $11-14$ & 2,500 & 0.98 \\
\hline $15-18$ & 2,500 & 0.98 \\
\hline $19-24$ & 2,500 & 0.98 \\
\hline $25-50$ & 2,500 & 0.98 \\
\hline $51+$ & 2,100 & 0.82 \\
\hline
\end{tabular}

* According to Recommended Dietary Allowances (RDA) for 1989 12;

** Age brackets used as the reference for establishing an adult's mean calorie requirements;

*** Additional 500kcal for breastfeeding, according to the RDA 12;

\# Additional 300kcal for pregnancy, according to the RDA 12.

the households' geographic location, grouped in regional categories, North/Northeast and South/Southeast/Central-West, and urban-versus-rural area.

\section{- Data analysis}

The number of adult-equivalent units and persons was estimated for both the total population and according to the socio-demographic variables.

The study's central variables - adult-equivalent and per capita calorie availability - were ini- tially described by central tendency and dispersal measurements for the population as a whole and according to geographic region, urban-versusrural area, and income.

The difference between adult-equivalent and per capita calorie availability was analyzed as the outcome variable in a multiple linear regression model containing a set of variables representing each of the gender, age group, and physiological state (pregnant or breastfeeding) categories used in constructing the adult-equivalent scale (Table 1) as explanatory variables. This model was used to estimate the predicted values for the difference 
between adult-equivalent and per capita calorie availability according to 15 different family compositions (assigning a value of 0 for the absent individual category or the number of individuals present in the category in each of the simulation scenarios). The study scenarios involved both males and females in different life cycle stages (children, adolescents, adults, elderly, pregnant women, and breastfeeding women). The model equation used in our study can be defined as:

Dif_AE_PC $=\alpha+\beta_{1}\left(\right.$ Age $\left._{0-1}\right)+\beta_{2}\left(\right.$ Age $\left._{1-3}\right)+$

$\beta_{3}\left(\right.$ Age $\left._{4-6}\right) \ldots+\beta_{24}\left(\right.$ Woman $_{\text {preg. }}$. Age $\left._{51+}\right)$

Where Dif_AE_PC is the difference between adult-equivalent and per capita calorie availability; Age $_{0-1}$ is the number of persons from 0 to 1 year of age in the family (first cell in the adultequivalent scale, Table 1); Age $_{2-3}$ : is the number of persons from 2 to 3 years of age in the family; ... : represents $n$ gender, age, and physiological state brackets; and Woman gest. $_{\text {Age }}$ (1+ $_{\text {: }}$ is the number of pregnant women and individuals 51 years de age or older in the family (last cell in the adultequivalent scale, Table 1).

The study's analytical procedures were performed with Stata version 9.2 (Stata Corp., College Station, USA) and considered all the aspects of the 2002-2003 Household Budget Survey and their effect on the standard errors for all the resulting estimates.

\section{Results}

Table 2 shows the total number of individuals and adult-equivalent units according to geographic region, urban-versus-rural area, and per capita income. Conversion of the number of individuals to adult-equivalent units resulted in important differences for all the studied scenarios, and this effect was greatest in the North/ Northeast, in the rural area, and in the lowest household per capita income tertile.

The measurements obtained from adultequivalent units were all higher than per capita measurements, suggesting underestimation of calorie availability if household composition is overlooked. The largest differences between per capita and adult-equivalent calorie availability were in the rural area and the lowest income tertile (Table 3).

Figure 1 showed the predicted value for the difference between per capita and adult-equivalent calorie availability for 15 different family compositions. The estimated difference was positive in all the scenarios, ranging from 22 to $428 \mathrm{kcal} /$ day, corroborating the underestima- tion of household calorie availability using per capita measurements. The differences between the two estimates increase even further in family compositions involving young children and older adults, whose energy requirements differ the most from those in 19 to 50-year-old adults (reference individual).

\section{Discussion}

Based on the records of food purchases in the 2002-2003 HBS, use of the adult-equivalent scale had an important impact on Brazil's household calorie availability estimates. The ratio between adult-equivalent and per capita calorie availability was always greater than 1 , indicating underestimation of calorie availability when household composition is overlooked. Although this effect was detected in all the simulation scenarios, it was particularly important in low-income and rural households.

Adult-equivalent scales have been used since the late 19th century. Although they are based on distinct principles, they have wide application in the field of economic studies 14,15 . Meanwhile, in other fields, like Nutrition, there has been little recognition of their importance or the possibilities for their application. This situation is aggravated by the use of scales developed with distinct methodologies and the lack of information on the elaboration of some of the available scales.

Most adult-equivalent scales currently used in nutritional studies are based on physiological coefficients, like calorie requirements. Thus, the main differences between these scales relates to the individual used as the reference (reference adult) and the choice of the set of calorie requirements $8,9,10$.

Importantly, the reference for the current study was an adult individual (age 19 to 50 years), regardless of gender, since the calorie requirements for men and women were used jointly to estimate the reference value. Thus, one can estimate an adult-equivalent scale capable of attenuating the impact of different age and gender compositions in the households. In addition, the wide adult age range used to define the reference individual guarantees good reliability for the scale proposed in this study.

In Brazil, the National Food Consumption and Family Budget Survey (ENDEF) led to the development of the first known adult-equivalent nutritional scale in the country, in the 1970s. The reference for that study was an adult male 20 to 29 years of age, with an energy requirement of $2,939 \mathrm{kcal} /$ day. The estimated factors varied from 
Absolute number of individuals and adult-equivalent calorie requirement units, according to geographic region, area (urban versus rural), and per capita income. Brazilian Household Budget Survey, 2002-2003.

\begin{tabular}{lccc}
\hline Indicators & Number of persons (a) & $\begin{array}{c}\text { Number of adult- } \\
\text { equivalent units (b) }\end{array}$ & $\begin{array}{c}(\mathbf{b} \times \mathbf{1 0 0}) / \mathbf{a} \\
\%\end{array}$ \\
\hline Geographic region & & & 88.54 \\
North/Northeast & $62,800,000$ & $55,600,000$ & 89.58 \\
South/Southeast/Central-West & $113,200,000$ & $101,400,000$ & 89.7 \\
Area & & & 88.7 \\
Urban & $146,000,000$ & $131,000,000$ & 88.3 \\
Rural & $30,000,000$ & $26,600,000$ & 89.2 \\
Per capita income tertiles (Reais) & & & 90.4 \\
1st & $65,700,000$ & $58,000,000$ & 89.2 \\
2nd & $60,200,000$ & $53,700,000$ & $45,300,000$ \\
3rd & $50,100,000$ & $157,000,000$ & \\
Total & $176,000,000$ & & \\
\hline
\end{tabular}

Table 3

Per capita and adult-equivalent calorie availability according to geographic region, urban-versus-rural area, and per capita income. Brazilian Household Budget Surveys, 2002-2003.

\begin{tabular}{|c|c|c|}
\hline \multirow[t]{3}{*}{ Indicators } & \multicolumn{2}{|c|}{ Calorie availability (kcal/day) } \\
\hline & Per capita & Adult-equivalent \\
\hline & Mean $(95 \% \mathrm{Cl})$ & Mean $(95 \% \mathrm{Cl})$ \\
\hline \multicolumn{3}{|l|}{ Geographic region } \\
\hline North/Northeast & $1,802.6(1,761.8-1,843.4)$ & $2,039.7(1,993.4-2,086.0)$ \\
\hline South/Southeast/Central-West & $1,812.4(1,748.2-1,876.7)$ & $2,022.3(1,951.4-2,093.1)$ \\
\hline \multicolumn{3}{|l|}{ Area } \\
\hline Urban & $1,691.6(1,647.4-1,735.9)$ & $1,895.1(1,846.0-1,944.3)$ \\
\hline Rural & $2,377.6(2,258.0-2,497.3)$ & $2,675.1(2,545.0-2,805.2)$ \\
\hline \multicolumn{3}{|l|}{ Per capita income tertiles (Reais) } \\
\hline 1 st & $1,553.8(1,505.1-1,602.5)$ & $1,790.3(1,734.0-1,846.5)$ \\
\hline 2nd & $1,845.5(1,773.5-1,917.6)$ & $2,061 \cdot 3(1,981 \cdot 2-2,141.4)$ \\
\hline 3 rd & $2,027.5(1,948.6-2,106.4)$ & $2,234.0(2,147.8-2,320.2)$ \\
\hline Total & $1,808.9(1,764.0-1,853.8)$ & $2,028.5(1,978.8-2,078.2)$ \\
\hline
\end{tabular}

0.30 (for children under one year of age) to 1 (for males 20 to 50 years of age), and the scale was based on international calorie requirements, according to guidelines from the Food and Agriculture Organization (FAO) and the World Health Organization (WHO) in the 1970s 1. For several years this scale was considered the official instrument for adult-equivalent conversion in nutritional studies ${ }^{15}$. However, its reference values are now outdated in relation to current knowledge (as to gender and age-specific calorie re- quirements), thus leading to serious limitations in its use. Therefore, the use of this scale should no longer be considered efficient.

In a study on the use of findings from household budget surveys to implement food fortification programs, the authors used a scale with an adult male over 20 years of age as the reference, based on calorie requirements recommended by FAO, highlighting the importance of using this tool. The set of adult-equivalent units were publicized by the study and varied from 0.27 (for 
Difference between per capita and adult-equivalent calorie availability according to different family compositions in households. Brazilian Household Budget Survey, 2002-2003.

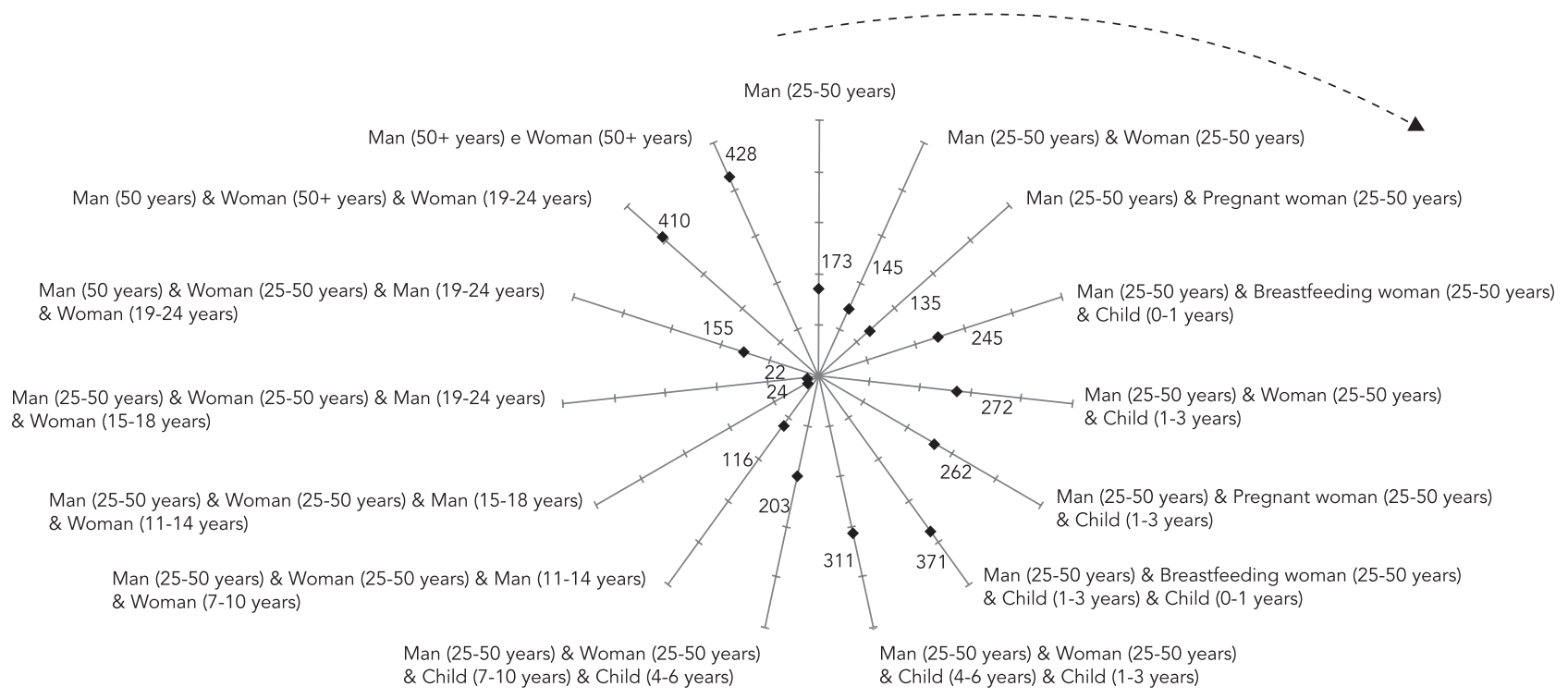

children under 1 year of age) to 1 (for males over 20 years of age) 10 .

The methodology used in the current study was similar to one in a study on the nutritional transition in Mexico, based on household budget surveys, and which also adopted a reference individual based on mean calorie requirements for adult men and women $(2,550 \mathrm{kcal})$, according to Recommended Dietary Allowances (RDA). However, the number of age groups used (and their respective factors) and the inclusion of pregnant and breastfeeding women in the scale were not sufficiently explained 9 .

Another Brazilian study compared the estimated national calorie availability values using the adult-equivalent scale from the ENDEF and per capita values. The authors also observed that the per capita values tended to underestimate the real calorie availability. Use of the adultequivalent scale also reduced the variability in household calorie intake, proving to be the most precise method for estimating calorie consumption using household budget surveys ${ }^{8}$.

In the same direction, studies on food demand in Brazil 16 and Turkey 17 also highlight the important influence of family composition on household dietary patterns, which provided the central justification for the use of adult-equiv- alent scales. The adult-equivalent concept was also used to standardize individual food, calorie, and macronutrient consumption in a study aimed at assessing the impact of economic policies on more vulnerable population groups in Vietnam (low-income individuals, rural residents, and ethnic minorities) 18 .

The current study's limitations relate to the methodology used to estimate the adultequivalent scale and to the database adopted for its application. Use of calorie consumption recommendations based on the American and Canadian population was necessary due to the lack of such recommendations for the Brazilian population. Although more recent recommendations for individual calorie requirements are available, like the Dietary Reference Intake and Human Calorie Requirements, such references do not define mean calorie requirements according to age group, gender, and physiological state, as proposed by the RDA 1989 12, and their application requires inferences concerning the target population's level of physical activity, weight, and height (information that is not fully available for the Brazilian population).

This choice may have reduced the estimated scale's precision (due to the gap between the calorie requirements used as the reference and 
the Brazilian population's real calorie needs), given the very nature of calculating these requirements 8,19 . Still, it is natural to believe that an adult-equivalent scale estimated from calorie requirement data estimated specifically for the Brazilian population would be similar to that estimated in our study. Meanwhile, the widespread use of this set of recommendations means that the estimated adult-equivalent scale is applied to national and international studies. As for the database used for the adult-equivalent scale, namely the 2002-2003 HBS, its main limitation is that it is impossible to identify the amounts of food actually consumed, given that information on eating outside the household could not be included in this study (i.e., such information was not collected in sufficient detail), and no information is available on the amount of food purchased but not consumed. Even so, there is no reason to believe that the direction of the relations found here would have been different if it had been possible to properly assess food consumption outside the home or even food wasted at home.

In short, the proposal for empirical application of the equivalence concept using household budget data resulted in more reliable information on food availability (since the concept considers the different individuals and their respective calorie requirements in the households' composition), indicating that the use of per capita measurements can underestimate real calorie availability. The use of an adult-equivalent scale could even provide a more accurate assessment of the trends in the Brazilian population's dietary pattern in the main metropolitan areas (studied in four periods since the 1970s), considering the changes in the country's household demographic composition in each period, thus aiding the definition and adjustments of public policies for food and nutrition and health.

\section{Resumo}

Objetivou-se estimar uma escala adulto-equivalente de necessidade energética e determinar as diferenças entre medidas adulto-equivalente e per capita para disponibilidade energética da população brasileira. Utilizaram-se dados da Pesquisa de Orçamentos Familiares de 2002/2003. A necessidade energética de um indivíduo adulto de referência baseou-se na média das necessidades de homens e mulheres adultos $(2.550 \mathrm{kcal} /$ dia). Os fatores de conversão foram definidos como a razão entre a necessidade energética de cada grupo de idade e sexo e aquela do adulto de referência. Os valores de disponibilidade de energia adulto-equivalente foram superiores aos per capita, sendo as maiores diferenças nos domicílios da área rural e de menor renda. As diferenças na disponibilidade energética domiciliar variavam entre $22 \mathrm{kcal} / \mathrm{dia}$ (domicílio contendo adultos e adolescente) e 428kcal/dia (domicílio onde residem idosos), demonstrando que medidas per capita podem subestimar a disponibilidade energética real, uma vez que ignoram diferenças na composição dos domicílios.

Consumo Alimentar; Inquéritos Nutricionais; Necessidade Energética

\section{Contributors}

R. B. Levy, R. M. Claro, D. H. Bandoni, and L. Mondini contributed to the study's planning and data analysis and writing of the article.

\section{Acknowledgments}

This article is part of a broader research project on the determinants of food composition using data from the Family Budget Surveys, with funding from the National Research Council (CNPq, grant number 475628/2009-8). 


\section{References}

1. Naska A, Vasdekis VGS, Trichopoulou A. A preliminary assessment of the use of household budget survey data for the prediction of individual food consumption. Public Health Nutr 2001; 4:1159-65.

2. Trichopoulou A, Naska A. European food availability databank based on household budget surveys: The Data Food Networking initiative. Eur J Public Health 2003; 13(1S):24S-8S.

3. Levy-Costa RB, Sichieri R, Pontes NS, Monteiro CA. Disponibilidade domiciliar de alimentos no Brasil: distribuição e evolução (1974-2003). Rev Saúde Pública 2005; 39:530-40.

4. Blaylock JR. The impact of equivalence scales on the analysis of income and food spending distributions. Western Journal of Agricultural Economics 1991; 16:11-20.

5. Tedford JR, Capps O, Havlicek Jr. J. Adult equivalent scales once more: a developmental approach. Am J Agric Econ 1986; 68:322-33.

6. Deaton AS, Muellbauer J. On measuring child costs: with applications to poor countries. J Polit Econ 1986; 94:720-44.

7. Vaz FM, Vaz KCS. Estimação de escalas de equivalência para o Brasil. In: Anais do XXXV Encontro Nacional de Economia. Niterói: Associação Nacional dos Centros de Pós-graduação em Economia; 2007. p. 2-30.

8. Vasconcellos MTL, Anjos LA. Taxa de adequação (ingestão/requerimento) de energia como indicador do estado nutricional das famílias: uma análise crítica dos métodos aplicados em pesquisas de consumo de alimentos. Cad Saúde Pública 2001; 17:581-93.

9. Rivera JA, Barquera S, Campirano F, Campos I, Safdie M, Tovar V. Epidemiological and nutritional transition in Mexico: rapid increase of non-communicable chronic diseases and obesity. Public Health Nutr 2002; 5(1A):113-22.

10. Fiedler JL, Smitz MF, Dupriez O, Friedman J. Household income and expenditure surveys: a tool for accelerating the development of evidencebased fortification programs. Food Nutr Bull 2008; 29:306-19.
11. Instituto Brasileiro de Geografia e Estatística. Pesquisa de Orçamentos Familiares 2002-2003: primeiros resultados. Rio de Janeiro: Instituto Brasileiro de Geografia e Estatística; 2004.

12. Food and Nutrition Board. Recommended dietary allowances. 10th Ed. Washington DC: Subcommittee on the 10th Edition of the RDAs, Food and Nutrition Board, Commission of Life Sciences, National Research Council; 1989.

13. Instituto Brasileiro de Geografia e Estatística. Estudo Nacional das Despesas Familiares - ENDEF: 1974-1975. Rio de Janeiro: Instituto Brasileiro de Geografia e Estatística; 1978.

14. Deaton A, Muellbauer J. Household characteristics, demand, and household welfare comparisons. In: Deaton A, Muellbauer J, editors. Economics and consumer behavior. Cambridge: Cambridge University Press; 1991. p. 191-213.

15. Vasconcellos MTL. Metodologia do Estudo Nacional da Despesa Familiar: objetivos, descrição e metodologia usada no ENDEF. Rio de Janeiro: Instituto Brasileiro de Geografia e Estatística; 1983.

16. Agüero JM, Gould BW. Household composition and Brazilian food purchases: an expenditure system approach. Canadian Journal of Agricultural Economics 2003; 51:323-45.

17. Sengul H. Equivalent scale on food consumption in Turkey. Journal of Applied Sciences 2006; 6:1172-5.

18. Thang NM, Popkin BM. Patterns of food consumption in Vietnam: effects on socioeconomic groups during an era of economic growth. Eur J Clin Nutr 2004; 58:145-53.

19. Anjos LA, Souza DR, Rossato SL. Desafios na medição quantitativa da ingestão alimentar em estudos populacionais. Rev Nutr 2009; 22:151-62.

Submitted on $27 / \mathrm{Jul} / 2009$

Final version resubmitted on 03/Dec/2009

Approved on 02/Feb/2010 